\title{
METAPHORICAL EXPRESSION IN MANADO MALAY
}

\author{
Kristian Rumengan, Deane J. Wowor, Tirza Kumayas
}

\begin{abstract}
The purpose of this study is to identify the metaphorical expression in Manado Malay and also to describe the meaning of those metaphors. Metaphor is a kind of figurative language which uses connotative meaning through the comparison without using the word "like" or "as". Most of metaphorical expression comes from a human behavior. The subject consisted of speakers of Manado Malay particularly the researcher himself and those who lives in Wuwuk village. The writer used descriptive research. Qualitative research is the suitable method to analyze the metaphorical expression. The writer used qualitative approach to find the actual data about metaphorical expression, the data collections are in the form of words, pictures, rather than numbers. The result shows that there are 53 metaphorical expressions in Manado Malay commonly used in everyday speech. It can be indicate by through, human's behavior, human's characteristics, and feelings, such as "Putar bale" which means someone who is lie and "Bobou seho" which means someone who has drunk. Some other metaphor is used to describe a circumstance such as, "ujang kopi" which mean zenithal rain or refer to the hot rainy weather conditions. It is expected that many other researches could be conducted especially the problem which concerned with metaphorical expression. Studying language and it's relation with metaphorical expression leave many question to answer. That is why, by conducting this research, other researchers can get some information about metaphorical expression in Manado Malay.
\end{abstract}

\section{Keywords: Metaphorical Expression; Manado Malay; Figurative Language}

\section{INTRODUCTION}

Since being born, human beings live in a certain neighborhood into a container. People need help from the others around them. For that people need to communicate. As social creatures, humans are always eager to talk, exchange-traded ideas, send and receive information, share experience, working with others to meet the needs, and so on. According to Nihta Liando dkk, (2018:1), "Communication is always important in everyday life. People need to communicate by using language to interact with other people and to express their feelings or share ideas and thoughts. In order to communicate, everybody has automatically learned their native language through their social environment since they were children". In communicating course people use language for the message to be received well by the recipient, use verbal or nonverbal language.

Language has a function as a tool of communication used by human to express their thoughts, feelings, desires, and action. It constitutes a natural means of communication possessed by every human. Due to this important role, researches on language are essential to be done for the sake of establishing and preserving language and culture (Sarah Kamagi dkk, 2018:847). Culture of a region is strongly influenced by its language users. Regional language or also known 
as the mother tongue is a symbol of the identity of a region, community, family, and environment (Ratu dan Maru, 2017:209).

In daily life, Manado Malay becomes very important in communication in North Sulawesi. It is just because Manado Malay is used as lingua franca by the people coming from different area who have their own native language. Beside it is used in Manado and its surroundings. Manado Malay is also used by Manadonese in foreign places or countries. It is the fact that the use of Manado Malay by Manadonese can merge the sense of friendship and kinship. Another fact according to Donal Ratu, dkk (2018:912), "The characteristics of Manado Malay speakers are open, spontaneous, blunt, and seem rude because mistakes in choosing speech patterns". Therefore, the expression sometimes creates misunderstanding; perhaps occur by usage figurative language.

Teilanyo (2007:310) "In fact, figurative use is common in everyday speech, employed to indicate the speaker's deep perception of or emotive identification with the idea being expressed". One of figurative languages that are usually used in literary works is metaphor. Metaphor is a kind of figurative language which uses connotative meaning through the comparison without using the word "like" or "as". Metaphor is considered difficult especially in understanding the meaning. It depends on the background knowledge of the readers. It needs a deeper attention since the comparison is conveyed implicitly. In literary works, metaphor takes an important role to communicate the complex material and convey it more effectively to the readers. Therefore, the writer's intention could be understood for the readers. Besides, metaphor could help the readers to catch the accurate insight of the writer physically and emotionally.

Metaphorical expressions are normally used in daily life whether it's in the middle of family, school, and in groups that existed in Wuwuk village. For example, the sentence: "memang kapala batu butul ngana" is a metaphor because the head (kepala) is a part of a person's body and the stone (batu) is a solid object. However, we can use this comparison to describe an association between the head of a human with a stone. The man with stone head means that is a stubborn.

There are still many examples of which can be found in a conversation every day that in doing the Wuwuk village community by using a dialect of Manado, but for most people who understand the intent of the metaphorical expression in acknowledged by someone will feel unusual because society in Wuwuk village, often using metaphorical expression in conversations every day. Metaphorical expression usually occurs because someone noticed any unusual or strange from someone so she concluded her but not to disclose based on the true meaning, and most metaphorical expressions in view of the behavior of a person. 
Well, from that explanation so that the author felt that the use of Metaphorical expressions is very important to learn and discussed.

\section{RESEARCH METHOD}

To prove this research about metaphor expression, the writer used descriptive research; it means qualitative research is the suitable method to analyze the metaphorical expression. "Qualitative research is descriptive research, the data collections are in the form of words, pictures, rather than numbers.” (Bogdan and Biklen, 1992:30).

The subject of this study is the Manado Malay's speakers who live in Wuwuk village, Tareran sub district, South Minahasa regency the province of North Sulawesi. These studies were taken based of the informants on the following criteria proposed by Nida (1959:12): (1) Native speakers of the language, (2) Adults who still actively speak the language, (3) Good speaking ability, (4) Good social relationship. The writer will use human instrument, which appear to function to fix the focus of research, selecting informants as a source of data, collecting data, assessing data quality, data analysis, interpret the data and make conclusions on the findings.

In collecting data the researches will use in-depth interviewing and document review technique. The collected data were analyzed according to the following steps: (1) Identifying the expressions, in this case indicate the metaphorical expressions in conversations, (2) Explaining their meaning; interpretation the expressions, (3) Describing their structure, thus they can be classified them into the phrase classification, such as verb phrase, noun phrase, and so on.

\section{ANALYSIS}

The first step taken when analyzing data is identifying the units that indicate metaphorical expression. Researchers found that there are 53 metaphorical expressions in Manado Malay commonly used in everyday speech. It can be indicate by through, human's behavior, human's characteristics, and feelings, and some other metaphor is used to describe a circumstance. 53 metaphors discovered by researchers are makang puji, nafas kuda, mati mantah, tidor ayam, lapar anjing, tangan besi, puru goro, hati kadondong, kaki gatal, kapala batu, mulu busu, nae darah, kuda kayu, talinga tipis, lidah sapi, calana tua, kaki botol, kaki kuda, tai minya, panta bensin, bobou goraka, bobou tanah, bobou naga, bobou seho, ampas tebu, haga miring, bangka dada, bobou pabrik, burung taon, mulu lebar, ilang jiwa, kalah panteto, makang untung, maso minta, mata busu, ujang panas, nae jin, panta putih, piara alus, kalah popoji sambiki dudu, sein 
alus, stengah mantah, taong adam, ujung kuku, cakar bebe, daong muda, ujang kopi, ujang keras, cirita konga, anak kalamarin, bulu nyawa, and kalah mata.

Among the 53 metaphorical expressions found, these are 5 examples of conversations in which there are metaphorical expressions in Manado Malay (the expressions containing metaphor are in bold.)

1. Conversation between two drivers at the station.

A : Butul so kata tadi ada orang cilaka di Kasuang? (Is it true that someone just crashed in Kasuang?)

B : Io ada. Kita riki so tako mo lewat situ lantaran mati mantah kwa depe korban noh. (Yes, it is. I even felt afraid to pass by there because the victim died raw.)

2. Conversation between two friends on the road.

A : Rasa nda ena badan kita eh lantaran tadi malam kwa da tidor cuma nda lama so bangun ulang! (I'm feeling unwell because last night I slept for a while and woke up again.)

B : Itu depe artinya ngana tidor ayam. (That means you sleep chicken.)

3. Conversation between two men in classroom waiting for the lecture.

A : Kiapa le ngana so ba feto? (Why are you nagging?)

B : Ngana pe tamang noh yang beking kita nae darah. (He likes to make me out of control.)

4. Conversation between a men and a woman at a party.

A : Oh tuhai so nda jaman ja pake tu celana kaki kuda bagitu eh. (Oh my God, it's so old fashion.)

B : Yah so ta nyaman kwa noh. (I'm so comfort with this.)

5. Conversation between two friends on the minibus.

A : Tuti, mabo ngana tadi malam kang? Masih kwa bobou seho yah. (Tuti, were you drunk last night? You smell like a beer.)

B : Io, mabo skali kwa kita tadi malam. (Yes, I was drunk last night.)

After identifying the units that show metaphor expressions, the next step is explaining their meaning (interpretation the expressions) and then describing their structure, thus they can be classified them into the phrase classification, such as verb phrase, noun phrase, and so on. This is the meaning of the five metaphor expressions that existed in the previous conversations.

1. Mati mantah

JELLT (Journal of English Language and Literature Teaching)

Vol. 5 No.01 June 2020

P.ISSN: 2548-7728 E.ISSN: 2599-0373 
This expression comes from two words "mati" and "mantah". Lexically "mati" is an adjective which means dead; "mantah" is an adjective which means raw; they become "dead raw". In Manado Malay this expression is a metaphors used for man who dies by accident.

2. Tidor ayam

This expression comes from two words "tidor" and "ayam". Lexically "tidor" is a verb which means sleep; "ayam" is a noun which means chicken; they become "chicken sleep". In Manado Malay this expression is a metaphors used for someone who can't sleep well.

3. Nae darah

This expression comes from two words "nae" and "darah". Lexically "nae" is an adjective which means ascend; "darah" is a noun which means blood; they become "ascend blood". In Manado Malay this expression is a metaphors used for an angry man.

\section{Kaki kuda}

This expression comes from two words "kaki" and "kuda". Lexically "kaki" is a noun which means leg; "kuda" is a noun which means horse; they become "leg horse". In Manado Malay this expression is a metaphors used for trousers with flared leg.

5. Bobou seho

This expression comes from two words "bobou" and "seho". Lexically "bobou" is an adjective which means smell; "seho" is a noun which means palm; they become "palm smell". In Manado Malay this expression is a metaphors used for someone who drank alcohol.

\section{CONCLUSION}

Metaphor is a figure of speech that makes an implicit, implied, or hidden comparison between two things that are unrelated, but which share some common characteristics. In other words, a resemblance of two contradictory or different objects is made based on a single or some common characteristics. After collecting, identifying, and analyzing the data concerning to metaphorical expression in Manado Malay, it can be indicate by through, human's behavior, human's characteristics, and feelings, such as "Putar bale" which means someone who is lie and "Bobou seho" which means someone who has drunk. Some other metaphor is used to describe a circumstance such as, "ujang kopi" which mean zenithal rain or refer to the hot rainy weather conditions. One's personality, including philosophy, culture, and standard of aesthetics and so on, will be reflected through the metaphor one uses. Only when the teaching methods of metaphors 
are employed properly can the students' creative thought and critical thinking skills be cultivated in the process of language learning.

\section{REFERENCES}

Liando, Nihta, Ray Sahetapy, and Mister Gidion Maru. English Major Students' Perception Towards Watching English Movies In Listening And Speaking Skills Development. Advances in Social Science Research Journal, Vol. 5, No. 6. 2018.

Kamagi, Sarah, Deane Wowor, Elizabeth Oroh, and Rully Rantung. A Study on Verbal Phrases in Tagulandang Dialect of Sangirese. Advances in Social Science, Education and Humanities Research, Vol. 226. 1st International Conference on Social Sciences (ICSS). 2018.

Ratu, Donal Matheos, and Mister Gidion Maru. Reduplication of Mongondow Language. A Journal of Culture, English Language, Teaching and Literature, Vol. 17, No. 2. 2017.

Ratu, Donal Matheos, Oldie Stevie Meruntu, and Wimsje Revlin Palar. Pragmatic Implicature of Manado Malay Speakers' Questions. Advances in Social Science, Education and Humanities Research, Vol. 226. 1st International Conference on Social Sciences (ICSS). 2018.

Teilanyo. Figurative Language in Translation: A Study of J.P. Clark's The Ozidi Saga in Meta. Journal Des Traducteurs / Meta: Translator's Journal Vol. 52, Page 309-326. 2007.

Bogdan, C. R. and Biklen S.K. Qualitative Research for Education. Bosto: Allyn and Bacon, Inc. 1992.

Nida, E. A. Componential Analysis of Meaning: An introduction to semantic Structures. Netherland: Mountain \& Co. Publisher. 1959. 